\title{
A VALÓSÁGOSAN LÉTEZŐ ABSZOLÚT PEDAGÓGUS
}

\section{THE REALLY EXISTING ABSOLUTE PEDAGOGUE}

\author{
Kiss Endre \\ DSc, professor emeritus, Országos Rabbiképző - Zsidó Egyetem, Budapest, ny. egyetemi tanár, \\ Eötvös Loránd Tudományegyetem, Budapest \\ dr.endre.kiss@gmail.com
}

\section{ÖSSZEFOGLALÁS}

Olyan pedagógusok életművét választottuk kutatási tárgynak, amelyek meghatározott kettős kritériumnak feleltek meg. Az első kritérium, hogy a kiválasztott pedagógus minősített és nyilvános önálló szellemi alkotó tevékenységgel kell hogy rendelkezzen. A második kritérium a pedagógiai, tanítási-oktatási teljesítmény kiemelkedő színvonala volt, valóságos oktatási helyzetekben, az iskolarendszer keretei között.

Az abszolút pedagógust különleges viszony füzi a gyermekhez. Ez igen komplex viszony, amely az érzelmi és az intellektuális közvetítéseken keresztül a történelemhez, a társadalom megjavításához, az utópiához, esetleg a közeledő történelmi katasztrófák elkerülésének egyetlen útjához, vagy éppen egy közelmúltbeli világégés új módon való elkerüléséhez vezet. Éppen ez az a mozzanat, amely valójában igazolja, helyére teszi és racionalizálja az abszolút pedagógusi életpálya különlegességét, bizonyos mérvű furcsaságát és különcségét is.

Az abszolút pedagógiai tevékenység nem elözetesen létezik egy ideális pedagógián kívüli térben, de magában az oktatási és nevelési folyamatban generálódik, nem egy elméletnek nevezhető komplexum megvalósítása, ami az azt megvalósító gyakorlattól függetlenül is valamiféle reflektált formában önállóan megjeleníthető.

\section{ABSTRACT}

Lifework of absolute pedagogues who meet a certain double criteria is chosen as the subject of the investigation. The first criterion stated that our protagonist provides a public, qualified, independent, and creative activity. The second criterion was that our protagonist has outstanding accomplishments in pedagogical activities in real teaching situations under the conditions of the school system.

The emerging model of the absolute pedagogue is linked to the children through a particular relationship. It might be a quite complex relationship that, through emotional and intellectual mediation, leads to history, to the improvement of society, to utopia, to ward off coming historical disasters or to avoid new shocks and dangers of re-emerging wars. This experiences of the children gain a structural importance. It is that moment that legitimizes, rationalizes and verifies the speciality and the extravaganza of a career in absolute pedagogy.

The activities of absolute pedagogy do not happen in ideal, out of pedagogy space they are generated within the teaching and educational processes. It is by no means the realization of a theoretical complex that can be perceived as a reflected ideal independent of practice. 
Kulcsszavak: abszolút pedagógia, kettős legitimáció, a gyermek strukturális pozíciója, valóságos oktatási folyamat, kreativitás, tudásterületek formalizáltsága

Keywords: absolute pedagogy, double legitimation, structural position of the child, real existing school, creativity, the formal character of the fields of knowledge

Az abszolút pedagógus rekonstrukciójára irányuló kutatás az értelmiségtörténet szélesebb összefüggésébe illeszkedik. Ebben a keretben kerestük kezdetben egészen általánosan a pedagógia helyét.

Azoknak a pedagógusoknak az életmüvét választottuk kutatási tárgynak, akik egy meghatározott, kettős kritériumnak feleltek meg. Az első kritérium, hogy a kiválasztott pedagógus minősített és nyilvános önálló alkotó tevékenységgel rendelkezzen. Minősítettnek azt az önálló (alkotó) tevékenységet tekintettük, amelynek színvonala és nagyságrendje megbízható ítéletalkotás után elégségesnek bizonyulhatott volna egy olyan életpálya befutására is, amely egyáltalán nem áll kapcsolatban a pedagógiával. Ebből azt a következtetést vontuk le, hogy ezek a pedagógusok érdemileg szabad választás után (legalábbis a szabadság érdemi részesedésével) választották a pedagógusi pályát. A második kritérium a pedagógiai, tanítási-oktatási teljesítmény minősítetten kiemelkedő színvonala volt, mégpedig valóságos oktatási helyzetekben, a valóságos iskolarendszer keretei között.

A kutatás nem a két teljesítmény puszta egymás mellé állítása, vagy e két teljesítmény valamiféle közös reflexiója volt, hanem a megvalósult oktatási tevékenység rekonstrukciója.

A kezdetektől lehetséges volt a negatív eredmény is. Ilyen esetekben rendelkezik valaki mindkét kritériummal, és mégsem jelentkezik megragadható és rekonstruálható minőség magában a tevékenységben. Arra is találtunk példát, hogy neves értelmiségi (író) jelentékeny pedagógiai tevékenységet fejt ki, de nem találtuk meg benne a gyermek iránti intenzív érdeklődésnek azt a szintjét, amelyet ugyancsak fontos és elvárt összetevőnek tekintettünk, ezért ebben az esetben az abszolút pedagógia megmaradt az alkotó önkifejezés médiumának.

Az „abszolút” jelző elsődleges értelme a szabad, semmivel nem összetéveszthető, autonóm pedagógiai gyakorlat sajátosságait akarta jelölni, ahogy például az „abszolút” zene is mindenképpen zene, de nem lehet összekeverni másokkal, levezetni másokból. A természetes nyelvek természete alapján nem lehetett kizárni a fogalomban rejlő más tartalmak érvényesülését sem, így például a „magas színvonal" attribútumát, de ez eleve másodlagos volt számunkra, már csak azért is, mert ez eleve szerepelt a definitív kiindulópontok között!

Mindkét félelmünk valamilyen mértékben mégis beigazolódott. A sajátosan az „abszolút pedagógiára” irányuló törekvéseink gyakran összekeveredtek a pedagógia más, jogosan értékelendő területeivel. De az a félelmünk is igazolódott, 
hogy többen az ,abszolút” jelzőt az „összehasonlíthatatlan” és „páratlan” pedagógiai tevékenység értelmében interpretálták, amellyel olyan elózetes értékválasztásokat tulajdonítottak nekünk, melyeket soha nem képviseltünk. Az „abszolút” terminus nem kitüntető cím vagy rang, hanem leíró jellemzés, amelynek konkrét kritériumai vannak.

A szakmák, illetve a tudásterületek különbségeiről voltak előzetes feltevéseink. Az egyes tudásterületek ugyanis nem egyképpen alkalmasak arra, hogy médiumukban az abszolút pedagógus kifejthesse munkáját. Lehetnek ezért területek, amelyeken vagy lehetetlen az abszolút pedagógia vagy a lehetetlenséggel határos az érzékelhetőség és a bizonyíthatóság esélyével kimutatni jelenlétét és sajátosságait. Mivel az abszolút pedagógus fogalmát eleve nem tekintettük kitüntetésnek, ezért az esetleges alkalmazhatatlanság sem vet fel igazságossági problémákat.

A kettős teljesítményt kutatva az alkotó tevékenység egyes müfajaiban minősítetten megszerzett jogosítványok megállapítása nem okozott különösebb nehézségeket. A küszöböt mindenekelött az jelentette, hogy az önálló alkotói életmü intellektuális minősége megüti-e azt a mértéket, hogy annak az oktatási munkába átsugárzó szinergetikus hatása megfelelhet eredeti elvárásainknak. A pedagógiai teljesítmény rekonstrukciójához ugyancsak valóságos információkra volt szükségünk. Egyformán fontosnak tekintettük az írásbeli forrásokat, de a legfontosabb szerepet e rekonstrukcióban e pedagógiai folyamat „tárgyai”, az egykori tanulók szisztematikus megkérdezése jelentette.

E célból munkaüléseket szerveztünk, amelyekre megkíséreltünk mind egykori tanulókat meghívni, mind pedig az illető protagonistáról eddig írt tanulmányok szerzőit erről a kérdésről is megkérdezni. E beszélgetések módszeres összejövetelek voltak, amelyek során nem kevés fáradságunkba került, hogy a legfontosabb tanúk minél pontosabban megértsék, mit értünk ,,abszolút pedagóguson”. De még ennél is nagyobb fáradságunkba került, hogy azt megértsék, miszerint a pedagógia számos okból méltán kiemelkedő teljesítményei közül minket csak ez az egy konkrét teljesítménytípus érdekel.

Az abszolút pedagógus és pedagógia akaratlanul is dialektikus jelenség. Definíció szerint ugyanis két, egymással ellentétes tulajdonságot foglalnak magukba. Egyfelöl nyilvánvaló, hogy egy ilyen kettős legitimációjú, a gyakorlati munkában realizálódó komplex teljesítmény eredeti lesz. Két abszolút pedagógus átlagon felüli egymáshoz való hasonlóságát nem lehet teljesen kizárni, mégis egyértelmüen abból kellett kiindulnunk, hogy maga a „pedagógia” szélsőségesen is eltérő lehet olyan alkotóknál, akikre egyébként egyformán ráillenek az alapvető meghatározások. Másfelöl az is nyilvánvaló, hogy a kiválasztott alkotók pedagógiájának közös vonásait kutatjuk, tudván tudva, hogy ezek a közös vonások egymástól definíció szerint eltérő, szinguláris életmüvekben lesznek fellelhetőek.

Kiemeljük szcientista hozzáállásunkat is. Mint a lelkiismeretes tudományos kutatásban mindenütt, a valóságosan közös vonások kimutatására összpontosí- 
tottuk erőinket, jóllehet ebben a különleges vizsgálatban intellektuális, erkölcsi, politikai és minden más szempontból számolatlanul látványos, helyenként egyenesen szenzációs felfedezést tehettünk, vagy az értelmiségtörténet olyan egyre újabb kérdéseibe merülhettünk volna el, ami nem volt feladatunk.

Az „abszolút” pedagógus jelzőjének értelme: a pedagógia egyfajta művészete, elmélete és gyakorlata. Nem az abszolút pedagógia eleve megállapított modellje vezetett el az egyes protagonistákhoz, de a meghatározott módon kiválasztott szereplők mủvének elemzéséből állítottuk össze e sajátos gyakorlat rekonstrukcióját.

Az abszolút pedagógus létmódjához az a tanuló is hozzátartozik, akiben az abszolút pedagógus közvetítette világ a közvetítő személyével együtt, mint a közvetités médiumában újjáépül. Mindazokon a munkamegbeszéléseken, amelyeken megjelentek egykori tanulók, és mindazokban a visszaemlékezésekben, amelyek differenciáltabb emlékezésről tettek tanúbizonyságot, a tanulók érzékelték, sőt, körvonalazni is tudták azt a médiumot, amely az abszolút pedagógus és közöttük kiépült. Sok évtizeddel később is érezhető volt az ebből az élményéből származó eufória. Szimpatikus és még a történeti igazságszolgáltatás szempontjából is lényeges módon annak is kifejezést adtak, hogy életük során előrehaladva egyre pozitívabb privilégiumnak tekintették, hogy ilyen nevelésben részesülhettek. Feltűnően sok volt az utalás arra is, hogy ez az oktatási élmény későbbi pályaválasztásukat is befolyásolta, ami nem egy nemzedék esetében még azt a változatot is magában foglalta, hogy az 1956-os disszidálás után könnyen tudtak olyan pályát választani, amelyre ugyan eredetileg egyáltalán nem gondoltak (mindent el tudtak képzelni, csak azt nem, hogy matematikaprofesszor lesz belölük), de amelynek birtokába éppen egy abszolút pedagógus munkája juttatta öket. Részlettanulmányaink kivétel nélkül tartalmazzák az abszolút pedagógus módszerei iránti megértést (beleértve nemritkán a szerencsés diáksors tényének örömteli felismerését is).

Egyetlen abszolút pedagógus sem lesz véletlenül az. Ez előzetes hipotéziseink között is szerepelt, hiszen az így értelmezett hivatás mind a „Beruf”, mind a munkahely, mind a „hivatás”, mind pedig a „küldetés” oldaláról különleges, nem tipikus, $\mathrm{s}$ nem is érhető el a normális pályakép vagy karrierépítés útján.

Az egzisztenciális döntés ténye erősebb vagy halványabb megvilágításban szinte mindenütt megjelent. Szembesülnünk kellett azzal is, hogy saját koruk nyilvánossága, ha egyáltalán érdeklődött is az abszolút pedagógusok sajátszerüsége iránt, ezt eleve más megközelítésből és más terminológiával tette, azaz nem azokat a kérdéseket tette fel a szereplőknek, amelyek éppen az abszolút pedagógus általunk megválasztott kritériumainak oldaláról hangzottak volna el.

Az egzisztenciális döntés ténye (legalábbis rekonstruálható árnyéka) feltesz nagy jelentőségű további kérdéseket is, amelyeket fel kell ismernünk, még ha nem is voltak megválaszolhatóak kutatásunk keretei között. Vajon nem volt-e kapcsolat az ilyen horderejü egzisztenciális döntések sorozata és az egzisztencialista fi- 
lozófia virágkorai között? És: vajon mely történeti, szociális és más okok vezettek ezeknek a döntéseknek a meghozatalához?

Az abszolút pedagógust különleges viszony füzi a gyermekhez. E különleges viszony filozófiai, illetve érzelmi elemeinek elsődlegessége eldönthetetlen, bár nem értelmetlen kérdésfeltevés. Ez igen komplex viszony, amely az érzelmi és az intellektuális közvetítéseken keresztül a történelemhez, a társadalom megjavitásához, az utópiához, a közeledő történelmi katasztrófák elkerülésének egyetlen útjához vagy egy közelmúltbeli világégés új módon való elkerüléséhez vezet.

Ez kutatómunkánk egyik legnagyobb eredménye. A gyermeknek a jövő embereként való közvetlen értelmezése strukturális jelentőségre tesz szert. Éppen ez az a mozzanat, amely igazolja, helyére teszi és racionalizálja az abszolút pedagógus életpálya különlegességét, bizonyos mérvü furcsaságát vagy különcségét is. Az abszolút pedagógus hivatásvállalásának szerves kiegészítője a gyermek történelmi, világtörténelmi szerepének értelmezése. A legnagyobb feladat megoldása érdekében kifejtett erőfeszítés nem értelmiségi vállalás, nem önmegvalósítás, nem különleges teljesítmény, de napi munka, kivételes normáltevékenység.

Nem találkoztunk olyan abszolút pedagógussal, akinél a gyermeknek ez a valamilyen értelemben spiritualizált értelmezése ne lett volna jelen. Találkoztunk viszont olyan neves és alkotó értelmiségivel, aki pedagógiai kísérletekbe kezdett, de saját önmegvalósítása, személyisége sokoldalúságának kinyilvánítása sokkal meghatározóbb motívuma maradt, mint a gyermek, emiatt nem is vettük fel őt az abszolút pedagógusok sorába.

Az abszolút pedagógiai tevékenység nem elözetesen létezik egy ideális pedagógián kivüli térben, de magában az oktatási és nevelési folyamatban generálódik. Az abszolút pedagógusnak nincsen saját tevékenységére vonatkozó elözetes elmélete. Ez még azokban a ritka esetekben is így van, amikor az abszolút pedagógus maga is éppen elméleti ember, sőt, minősített intellektuális szakterületei között még a pedagógiai elméletírás is szerepel. Az abszolút pedagógia egyedüli médiuma az abszolút pedagógus „érdemi” iskolai tevékenysége. Nem hagytuk figyelmen kívül a különleges, azaz iskolán kívüli oktatási helyzetekben megvalósítható abszolút pedagógiai magatartást sem (Leopold Mozart), az ilyeneket azonban, mint alapvetően más jelenséget, ki kellett zárnunk érdeklödési körünkből.

Az abszolút pedagógia az iskolai tevékenységben mint médiumban realizálódik. Ilyen alapon párhuzamba hozható a müvészet jelenségkörével is. A müvész és a müélvező kapcsolata is tudatos, a müvészt is határozott akarat vezeti, senki sem ír vagy vezényel véletlenül szimfóniákat. A müalkotás közegében is tartalmak, jelenségek, affektusok és lelki jelenségek hatalmas tömege kerül közvetítésre. Minden müalkotás ugyanúgy egyszeri és egyedi, miközben az egyes müfajok gond nélkül jellemezhetőek holisztikusan is. A zene médiuma az előadás, $a z a b$ szolút pedagógia médiuma az oktatási folyamat. 
Mivel az abszolút pedagógia csak magában az oktatási folyamatban realizálódik, elvileg sem végezhető második vagy harmadik hivatásként. Az abszolút pedagógiában a tudásformák és tudásterületek igen nagy száma között jöhet létre oszcilláló transzferhatás, mindez azonban csak az abszolút pedagógiának megfelelő müködési keretben történhet.

Ahogy nincs az abszolút pedagógusnak saját olyan elmélete, amely konkrétan az abszolút pedagógiai tevékenységet alapozná meg, úgy olyan saját filozófiája sincs, amelynek kizárólag ez lenne a célja. Ha tisztán filozófia-központú elemzést végeznénk, ezen a helyen próbálkozhatnánk a pragmatizmus vagy a praxisfilozófia elemeivel is, de még ha ez az út nem is lenne teljesen eredménytelen, akkor sem szolgálhatna a pedagógiai elemzés megoldásaként, mivel a teljes pedagógiai leírást normálfilozófiai alesetté transzponálná át. Ez a vonás segít jobban megérteni mind az abszolút pedagógus tevékenységét, mind pedig a hivatást magát. Olyan „mondanivaló” kifejezése az abszolút pedagógia, amely más médiumban nem lenne kifejezhetö. Az üzenet az, amely kifejezési formát (médiumot, közeget) keres magának.

Ha előbb a művészet, a zenei előadás jelentett számunkra megvilágító érvényủ analógiát, most a szecesszió elméletét értelmező müvészettörténészek mühelyében kialakuló müvészetakarás a megfelelő analógia. Az „akarást” nem fejezheti ki egy, azt megfogalmazó elmélet vagy filozófia, a művészetakarás a vizuális ábrázolás médiumában tör magának utat, létezését és határozott gravitációs irányát, elképzeléseit azok meghatározottságaival maga a mü demonstrálja. Az abszolút pedagógusnak ugyan nincs önállóan megjeleníthető teóriája vagy filozófiája, de nagyon is van „pedagógia”-akarása, amely az ő abszolút pedagógiájában végső soron a gyermek/tanuló személyiségében akkor is megvalósul, ha esetleg nem is akarja vagy nem is tudná fogalmakban megszövegezni annak lényegét.

Tapasztalataink feldolgozása során megjelent a 'világszerüség' fogalmának nélkülözhetetlensége is. Ezt a fogalmat eddig elsősorban az esztétika használta, mert az egésznek, a totalitásnak olyan megjelenését jelöli, amely nem felel meg meghatározott egzakt kritériumoknak. A világszerüség azonban mégis átélhető intellektuális, morális és társadalmi struktúrákat képes megjeleníteni. Az abszolút pedagógia, amit az oktatás médiuma valósít meg, ugyancsak rendelkezik a világszerüség karakterével, és még abban is hasonlít a fogalom esztétikai használatára, hogy egészében meghatározatlan tárgyiassága minden konkrét pillanatban és helyzetben meghatározott. Annyiban is meghatározatlan a világszerüség, hogy nem lehetséges a médiumban realizálódó „világot” valamilyen módon reprodukálni. Más kérdés, hogy erre nincs is szükség, hiszen az abszolút pedagógia mint gyakorlat egyáltalán nem végcél. Annak a tanulók világában kell továbbélnie, alakítania kell a tanuló későbbi attitüdjét, és még mint work in progress idővel még azt is fel kell vennie magába, amit az egykori tanuló majd a jövőben lát, tanul 
és érez. A világszerüség természetesen az abszolút pedagógus definitív strukturális pozíciójából is fakad.

Az abszolút pedagógus karizmatikus müködésének valóságát a munkamegbeszélések igazolták. Karizmatikussá az abszolút pedagógust müködésének az a sokszínűsége teszi, amelynek közös centrumát a szóban forgó protagonista a maga módján („épp így lét”) testesíti meg.

A karizmában elvileg az összes lényeges meghatározás egyesül, azok összegeződő és összegező hatása „fókusz-” és „,eredő jellegü”. Mindebben természetesen benne foglaltatik, hogy a meghatározó tulajdonságoknak nagyobb szerepük van (így a kettős legitimációnak, a tudástranszfernek, a saját világszerüségnek, a megszokott konvenciók elkerülésének és új, közös konvenciók kialakításának stb.), de a karizma végső „eredőjében” egyáltalán nemcsak a tudomány vagy a szakma szempontjából fajsúlyos mozzanatok játszanak szerepet, hanem akár a legapróbb és legszemélyesebb részletek, ha tetszik, az „emberi” mozzanatok is (Nietzsche máig nem kellően megértett kezdeményezésével, az „emberi, nagyon is emberi").

Megtaláltuk a világszerüségnek egy olyan alulról felépülő sajátos mozzanatát is, amelyik nem „felülről” lefelé (például a tudástranszfer magasságából), de „alulról” fölfelé épül. A pedagógiai működés közvetitési lánca ez, amely az abszolút pedagógusoknál rendkívül hosszú. Az iskolán belüli tevékenység hosszú láncban hosszabbodhat meg az iskolán kívülivel, a tantárgyközpontú szakmai a nem tantárgyközpontú szakmaival, a tudományos a müvészivel, a hivatásrendi magatartás a személyes viszonnyal. Ismét más jellegü közvetítési láncokat hozhat létre a polihisztori mozzanat, a tudástranszfer, az interdiszciplinaritás. Ezek is mind közvetítések, áttételek, amelyeknek nincsenek elvi korlátai.

Tudatosan vagy öntudatlanul, az abszolút pedagógus sokkal jobban kinagyítja az oktatási folyamat egyes elemeit, sokkal több apróbb elemre bontja fel, s azon belül sokkal élesebben is különbözteti meg az egyes részleteket. Az alapvető metafora itt a „felbontóképesség”.

A közvetítési lánc tökéletesen objektív hasonlat, minden esetben megfeleltethető a valós oktatási folyamat elemeinek. Rendkívül fontos kifejtett módon is megfogalmazni, hogy ez az „elemtan” (egyelöre ugyancsak metaforikusan használva a kora újkori filozófia és tudomány e fogalmát) két olyan dimenzióval rendelkezik, amelyek konkrét szövegösszefüggésekben össze is keveredhetnek egymással.

Az egyik dimenzió az a közvetítési láncban érzékelhető felbontóképesség, ez „mélységi” dimenzió, a didaktikai, gondolkodási folyamat olyan általában nem realizált mélységi felbontása, amely szinte már e szint felderítésével megoldásokat is jelent, gondolkodási, tanulási vagy magatartásbeli dilemmákat, mint ahogy az is egyszerre triviális és egyben nagy jelentőségü felismerés, hogy ha a tanuló úgy érzi, hogy - ebben a felbontásban - igazán megértik személyiségét, nemcsak 
a „viszonya” képes radikálisan megváltozni az együttmüködéshez, de egész személyisége is.

A közvetítési lánc és az átlagon felüli felbontóképesség második dimenziója a hosszúság, a pedagógia elemi mozzanatainak a „lehető leghosszabb” közvetítési sorba való beillesztése. E lánc lehetséges elemeire már utaltunk. Más jellegü közvetítési láncokat hoz létre a tisztán polihisztori mozzanat. A tiszta fogalmúan „polihisztori' tanítás persze ugyancsak mozoghat kivételesen hosszú közvetítési láncon, anélkül hogy ettől önmagában már abszolút pedagógusnak kellene lennie.

Talán éppen e kivételes felbontás kiépíthetőségének lehetősége az a hivatásbeli kihivás, ami a pedagógia felé vonzza azt az alkotót, akiről az volt kiinduló előfeltételünk, hogy egy másik alkotó hivatásban is létrehozott értékeket. Az egyre hosszabbá váló közvetítési lánc egyre apróbb részletekre való felbontásának kihívása ez, amelyek a tematika részleteitől a tanuló személyiségének részleteiig, a szervezés részleteitől a pszichológia részleteiig, a nevelés erkölcsi részleteitől annak kognitív részleteiig, a társadalmi fontosság részleteitől a szellem tiszta területeinek részleteiig terjednek, olyan különleges feladat, amit csak ebben a tevékenységi körben lehet művelni.

A kivételesen hosszú közvetítési lánc, a kivételesen alapos „felbontás” csak „alulról” épülhet, és magába kell foglalnia a leghétköznapibb fejlődéstörténeti mozzanatoktól az ember történelmi hivatásáig gyakorlatilag mindent. Ez az „alulról” épülés világos alternatívája a „felülröl” való épülésnek, és ezen a ponton már az is látható, hogy az alkotó szerep (azaz az abszolút pedagógusban rejlö önálló alkotó lénye, azaz a nem pedagógus lénye) csak ,felülről” lehetséges.

Az abszolút pedagógusnak az oktatás médiumában realizálódó tevékenysége innovatív tartalmakat is hordoz. Itt is világos, hogy ez az intellektuális tartalom nem különíthető el ettől a gyakorlattól. S ha csak a kivételes felbontóképességre vagy az ugyancsak kivételesen hosszú közvetítési láncra gondolunk, nyomban világos, hogy ezek számolatlanul veszik fel magukba a legkülönfélébb intellektuális impulzusokat. Ezért az intellektuális tartalmat nem az elemi szinten, hanem az egész tevékenység összegeződéseként, a már használt kifejezéssel, „,eredőjeként” kíséreljük meg meghatározni. Azt a szellemi teret tartjuk meghatározónak, amely az abszolút pedagógia médiumának gyakorlása közben nyílik ki, válik asszociatívan átélhetôvé, hasonlóan ahhoz az ugyancsak intellektuális térhez, amely például egy Shakespeare-tragédia átélése közben kialakul: az intellektuális tartalmak kicserélődnek, a fogékonyság nő, tere nyílik a játéknak, a humornak, a hangulat egységes változásának. Az intellektuális áram (ebben az alkalmazásban erősen Henri Bergsonra emlékeztetően) szellemi minőségéről van szó, amit így, intellektuális (kulturális, civilizációs) szinten élnek át.

A kivételesen hosszú közvetítési lánc és a kivételesen mély felbontóképesség egyenként, de együttesen is átfedik a kreativitás fogalomkörét. Az abszolút pedagógus tevékenysége sajátos teremtési folyamat. Ezen a ponton ismét igazolva 
látjuk az „abszolút” jelző használatát, mert abban a kreativitásnak mind megsokszorozódása, mind kialakuló szinergetikus létezésének ténye megfogalmazást nyerhetett.

Az abszolút pedagógia többszörös mutáció is. Mutáció a tanári szerep reális, realizálódó médiumában, mutáció az oktatási folyamatban és szerencsés módon mutáció a tanulók számára. A részvevő mozzanatok maguk fölé emelkedhetnek, az alkotás, a kreativitás a tanuló közvetlen élménye lehet. Viszonylag sokan tettek tanúságot saját nyelvükön ennek az ugrásnak az élményéről is, amit e többszörös mutáció váltott ki. Színházi hasonlatainkat folytatva, ez a mutáció a katarzisnak megfelelő mozzanat. Nem elsősorban a többször is megvalósuló közvetlenül katartikus elemekre gondolunk, hanem az abszolút pedagógia médiumában permanensen benne rejlő, bármikor realizálódó katartikus dimenzióra. A „megnőtt élet", az élet új magasságokba való emelkedése a mindenkor megvalósulás küszöbén álló ugrás.

Az abszolút pedagógust, köznyelven kifejezve, egy „idealista” vonás jellemzi. Ezt az ,idealizmust”, ezt az erkölcsi komponenst ugyancsak komplexnek, elsősorban sajátos alázatnak kell látnunk, amely nélkül az abszolút pedagógiához vezetö egzisztenciális döntés, a gyermek kivételes szerepének elismerése, valamint a tudás egészének szeretete elképzelhetetlen lenne. Talán ez az alázat mozgatja azt a démont is, amelyről az egyik abszolút pedagógus beszélt. 